\title{
Psychiatric Morbidities of Elderly Out-patients Attending Various Out- reach Clinics in Gandaki Province of Nepal: A Descriptive Cross-sectional Study
}

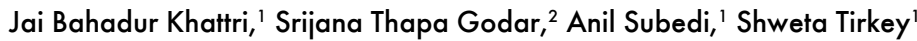 \\ 'Department of Psychiatry, Manipal College of Medical Sciences, Pokhara, Nepal, ${ }^{2}$ Department of Ophthalmology, Manipal \\ College of Medical Sciences, Pokhara, Nepal.
}

\section{ABSTRACT}

Introduction: Dramatic growth of the aging population resulted in an increased number of mental disorders and such data are limited in Nepal. The objective is to find out the psychiatric morbidities of elderly out-patients attending Baglung, Kusma, Walling, and Dumre out-reach clinics in Gandaki Province of Nepal.

Methods: This was a descriptive cross-sectional study conducted in 392 patients attending out-reach clinics of Baglung, Kusma, Walling, and Dumre of Gandaki Province for one year with the convenient sampling method. Ethical approval was taken from the Institutional Review Committee of Manipal College of Medical Sciences, Pokhara. The diagnosis was done according to the International Classification of Disease-10 guidelines. Epi-info 7 was used and point estimate at 95\% Confidence Interval was calculated along with frequency and proportion for binary data and the analysis was done.

Results: The prevalence of neurotic, stress-related, and somatoform disorders 145 (37.0\%) was maximum followed by mood disorders 111 (28.3\%). Maximum cases were in between 66 and 75 years, Brahmin and Chhetri caste, females, married, and from an extended nuclear family. There is more prevalence of female gender in all psychiatric diagnoses except in mental and behavioral disorders due to psychoactive substance use. There is more prevalence of age groups of patients less than or equal to 75 years in all the psychiatric diagnosis.

Conclusions: Neurotic, stress-related, and somatoform disorders were the most common diagnosis. The risk of development of certain disorders based on gender and age group of the patients would be helpful for case identification.

Keywords: aging; cross-sectional studies; Nepal; prevalence.

\section{INTRODUCTION}

The aging of the populations has become a worldwide phenomenon. ${ }^{1}$ This phenomenon has extensive consequences. ${ }^{2}$ Population aging is producing changes to the demographics of the developing countries like Nepal. ${ }^{3}$ The people aged above 65 years in Nepal comprises $5.42 \%$ in 2011 which is projected to increase to $6.79 \%$ of the total population in 2031.4

This phenomenon has dramatic consequences for public health, health care financing, and delivery systems in the whole world. Mental disorders are common chronic conditions among elderly people, and the absolute number of subjects with psychiatric disorders will increase dramatically soon worldwide. ${ }^{5}$

Correspondence: Dr. Jai Bahadur Khattri, Department of Psychiatry, Manipal College of Medical Sciences, Phulbari, Pokhara, Nepal. E-mail: jai2062@gmail.com, Phone: +977-9846071402. 
A plan is needed for provisions of services to elderly persons with mental disorders. ${ }^{6}$ The objective is to find out the psychiatric morbidities of elderly out-patients attending Baglung, Kusma, Walling, and Dumre outreach clinics of the Gandaki Province of Nepal.

\section{METHODS}

This descriptive cross-sectional study was conducted in all the elderly patients of above 65 years who attended the psychiatry out-patients department (OPD) of outreach clinics of Baglung, Kusma, Walling, and Dumre in the Gandaki Province of Nepal for one year (from November 2018 to October 2019). An equal number of patients $(n=98)$ were selected from each of the four clinics. All the elderly patients of above 65 years who attended Psychiatry OPD of out-reach clinics of Baglung, Kusma, Walling, and Dumre in the Gandaki Province of Nepal were included in the study. The elderly patients with acute medical or surgical emergency conditions were excluded from the study. The ethical approval of the study was taken from the Institutional Review Committee of Manipal College of Medical Sciences, Pokhara (MEMG/IRC/192/GA) before the start of the study.

The sample size was calculated by using the following formula,

$$
\begin{aligned}
& n=Z^{2} \times p \times q / e^{2} \\
& =(1.96)^{2} \times(0.375 \times 0.625) /(0.05)^{2} \\
& =360
\end{aligned}
$$

where,

$\mathrm{n}=$ sample size

$Z=1.96$ at $95 \% \mathrm{Cl}$

$p=$ prevalence, $37.5 \%^{7}$

$q=1-p$

$e=$ margin of error, $5 \%$

By adding 32 more samples ( $9 \%$ as non-response rate), the final sample size was calculated to be 392 .

The written informed consent was taken from the patients. The consent was taken from the relatives of the patients in case if the patient was unable to give consent because of an unstable mental state. The confidentiality of the participants was maintained.

The convenience sampling method was used. Selection and information bias has been minimized as possible. Data entry and analysis was done in Epi-info version 7. Point estimate at $95 \%$ confidence interval was calculated along with frequency and proportion for binary data and analysis was done.

A self-designed proforma was used to record the sociodemographic profile of the patients. The diagnosis of the elderly patients was based on International Classification of Disease-10 guidelines. ${ }^{8}$

\section{RESULTS}

A total of 392 consecutive elderly patients was selected for the study. The prevalence of neurotic, stress-related, and somatoform disorders 145 (37.0\%) was maximum followed by mood disorders 111 (28.3\%).

The sociodemographic profile of the patients is shown (Table 1).

\begin{tabular}{|lc|}
\hline \multicolumn{2}{|l|}{ Table 1. Socio-demographic profile of the patients. } \\
\hline Socio-demographic variables & $\mathbf{n}(\%)$ \\
Age groups (in years) & \\
$66-75$ & $336(85.7)$ \\
$76-85$ & $51(13.0)$ \\
$>86$ & $5(1.3)$ \\
Gender & \\
Female & $214(54.6)$ \\
Male & $178(45.4)$ \\
Caste & \\
Brahmin and Chhetri & $239(61.0)$ \\
Mongolian & $93(23.7)$ \\
Newar & $13(3.3)$ \\
Others & $47(12.0)$ \\
Marital status & \\
Married & $249(63.5)$ \\
Separated & $23(5.9)$ \\
Unmarried & $8(2.0)$ \\
Widow/widower & $112(28.6)$ \\
Type of family & \\
Extended nuclear & $219(55.9)$ \\
Joint & $133(33.9)$ \\
Nuclear & $40(10.2)$ \\
Total & $392(100)$ \\
\hline
\end{tabular}

Mean age $\pm \mathrm{SD}=69.86 \pm 5.04$ years

The majority of the patients were from the age group between 66 and 75 years $336(85.7 \%)$, females 214 $(54.6 \%)$, Brahmin \& Chhetri caste 239 (61.0\%), married $249(63.5 \%)$ and from the extended nuclear family $219(55.9 \%)$. The mean age of the patient was $69.86 \pm 5.04$ years.

The distribution of respondents as per the diagnosis based on International Classification of Diseases-10 guidelines is shown (Table 2). The majority of the cases were found to be suffering from neurotic, stressrelated, and somatoform disorders 145 (37.0\%). This 
was followed by a mood disorder 111 (28.3\%).

\begin{tabular}{|c|c|c|}
\hline TCD-10 diagnosis & TCD-10 code & n (\%) \\
\hline $\begin{array}{l}\text { Organic, including } \\
\text { symptomatic, } \\
\text { mental disorders }\end{array}$ & F00-F09 & $30(7.7)$ \\
\hline $\begin{array}{l}\text { Mental and } \\
\text { behavioral } \\
\text { disorders due } \\
\text { to psychoactive } \\
\text { substance use }\end{array}$ & F10-F19 & $15(3.8)$ \\
\hline $\begin{array}{l}\text { Schizophrenia, } \\
\text { schizotypal and } \\
\text { delusional disorders }\end{array}$ & F20-F29 & $12(3.1)$ \\
\hline Mood disorders & F30-F39 & $111(28.3)$ \\
\hline $\begin{array}{l}\text { Neurotic, stress- } \\
\text { related and } \\
\text { somatoform } \\
\text { disorders }\end{array}$ & F40-F48 & 145 (37.0) \\
\hline Headache & G43\&44 & $3(0.8)$ \\
\hline Seizure disorder & G40\&41 & $4(1.0)$ \\
\hline $\begin{array}{l}\text { Movement } \\
\text { disorders }\end{array}$ & G25 & $6(1.5)$ \\
\hline $\begin{array}{l}\text { Other organic } \\
\text { disorders }\end{array}$ & & $62(15.8)$ \\
\hline No diagnosis & & $4(1.0)$ \\
\hline Total & & 392 (100.0) \\
\hline
\end{tabular}

The distribution of the psychiatric diagnosis according to the gender of the patients is shown (Table 3). All the psychiatric diagnosis was prevalent among female gender except in mental and behavioral disorders due to psychoactive substance use.

\begin{tabular}{|c|c|c|c|}
\hline \multirow[t]{2}{*}{ Diagnosis } & \multicolumn{3}{|l|}{ Gender } \\
\hline & $\begin{array}{l}\text { Female } \\
\text { n (\%) }\end{array}$ & $\begin{array}{l}\text { Male } \\
\text { n (\%) }\end{array}$ & $\begin{array}{l}\text { Total } \\
\text { n (\%) }\end{array}$ \\
\hline $\begin{array}{l}\text { Organic, } \\
\text { including } \\
\text { symptomatic, } \\
\text { mental } \\
\text { disorders }\end{array}$ & $17(56.66)$ & $\begin{array}{l}13 \\
(43.33)\end{array}$ & $\begin{array}{l}30 \\
(100)\end{array}$ \\
\hline $\begin{array}{l}\text { Mental and } \\
\text { behavioral } \\
\text { disorders } \\
\text { due to } \\
\text { psychoactive } \\
\text { substance use }\end{array}$ & $3(20.00)$ & $\begin{array}{l}12 \\
(80.00)\end{array}$ & $\begin{array}{l}15 \\
(100)\end{array}$ \\
\hline
\end{tabular}

\begin{tabular}{|llll|}
$\begin{array}{l}\text { Schizophrenia, } \\
\text { schizotypal }\end{array}$ & 8 (66.66) & 4 (33.33) & 12 \\
and delusional & & & $(100)$ \\
$\begin{array}{l}\text { disorders } \\
\text { Mood disorders }\end{array}$ & $63(56.75)$ & 48 & 111 \\
& $93(64.13)$ & 52 & $(100)$ \\
Neurotic, & $93.24)$ & 145 \\
stress- & & $(35.86)$ & $(100)$ \\
related and & & & \\
somatoform & & & \\
disorders & & & \\
\hline
\end{tabular}

The distribution of the psychiatric diagnosis as per the age groups is shown (Table 4). All psychiatric illness is prevalent among patients less than or equal to 75 years.

\begin{tabular}{|c|c|c|c|}
\hline \multirow[t]{2}{*}{ Diagnosis } & \multicolumn{3}{|c|}{ Age groups (years) } \\
\hline & $\begin{array}{l}\leq 75 \\
\text { n }(\%)\end{array}$ & $\begin{array}{l}>75 \\
n(\%)\end{array}$ & $\begin{array}{l}\text { Total } \\
\text { n (\%) }\end{array}$ \\
\hline $\begin{array}{l}\text { Organic, } \\
\text { including } \\
\text { symptomatic, } \\
\text { mental disorders }\end{array}$ & $18(60.00)$ & $\begin{array}{l}12 \\
(40.00)\end{array}$ & $\begin{array}{l}30 \\
(100)\end{array}$ \\
\hline $\begin{array}{l}\text { Mental and } \\
\text { behavioral } \\
\text { disorders due } \\
\text { to psychoactive } \\
\text { substance use }\end{array}$ & 14 (93.33) & $1(6.66)$ & $\begin{array}{l}15 \\
(100)\end{array}$ \\
\hline $\begin{array}{l}\text { Schizophrenia, } \\
\text { schizotypal } \\
\text { and delusional } \\
\text { disorders }\end{array}$ & $12(100)$ & 0 & $\begin{array}{l}12 \\
(100)\end{array}$ \\
\hline Mood disorders & $\begin{array}{l}102 \\
(91.89)\end{array}$ & $9(8.10)$ & $\begin{array}{l}111 \\
(100)\end{array}$ \\
\hline $\begin{array}{l}\text { Neurotic, stress- } \\
\text { related and } \\
\text { somatoform } \\
\text { disorders }\end{array}$ & $\begin{array}{l}130 \\
(89.65)\end{array}$ & $\begin{array}{l}15 \\
(10.35)\end{array}$ & $\begin{array}{l}145 \\
(100)\end{array}$ \\
\hline
\end{tabular}

\section{DISCUSSION}

The elderly population is rapidly growing as compared to other populations around the world in the present century. The health sectors of the countries like Nepal should have proper planning to deal with the growing medical and psychiatric needs of this population to reduce the sudden negative impact of this population in the health infrastructures in the future.

There were 392 cases aged more than 65 years who 
Khattri et al. Psychiatric Morbidities of Elderly Out-patients Attending Various Out-reach Clinics in Gandaki Province of Nepal...

visited the out-reach clinics are selected for the study. The maximum number of patients falls in the age group between 66 and 75 years 336 (85.7\%). Different studies also found maximum cases in the younger elderly age-group. ${ }^{9-19}$ The mean age of the patients was 69.86 years with a standard deviation of 5.04 years in the current study. This finding was also following a study conducted in Nepal. ${ }^{17,20}$ This could be explained by the life expectancy of the Nepalese population and less number of patients is likely to survive in the advance age. ${ }^{4}$

There are more females as compared to males in the current study. This finding was following the studies done both in Nepal and India. ${ }^{15,16,19,21}$ However, the different studies found more male respondents in their sample of the population. ${ }^{10-12,14,17,20}$

Majority of the respondents were Brahmins \& Chhetri $239(61.0 \%)$ followed by Mongolians 93 (23.7\%), others (Dalits) 47 (12.0\%) and Newars 13 (3.3\%) in the current study. A similar trend has been found in the different studies conducted in Nepal. ${ }^{14,16,17,20}$ According to one study, the Brahmins and Chhetri are more aware of psychiatric illness and their treatment due to the privilege of higher education/ socio-economic status. ${ }^{20}$ There is a higher proportion of the distribution of Brahmin and Chhetri caste in the total national census of Nepal as well. ${ }^{4}$

Maximum cases in the out-reach clinics were married in the present study. The different studies also found the maximum number from the married group. $9,15,17,19,20$ Better support system of the married patients can explain this finding. ${ }^{20}$ However, a well-designed populationbased case-control study is needed to establish this finding.

In the present study, about $55.9 \%$ and $33.9 \%$ of the cases come from extended nuclear and joint family respectively. This finding also consistent with the one study conducted in Nepal. ${ }^{17}$ The study conducted in India concluded that family setting continues to be available for the elderly in the developing country. ${ }^{9}$

This study found that the maximum proportions of elderly citizens are suffering from neurotic, stressrelated, and somatoform disorders (37.0\%). One study was done in a rural setting inside Nepal also found maximum respondents to be suffering from somatization and generalized anxiety. ${ }^{22}$ However, the different studies found maximum senior citizens to be suffering from mood disorders. ${ }^{13,15,16,18,23}$ One study conducted in Nepal found maximum patients to be suffering from psychosis. ${ }^{14}$ These overall findings reflect that if the study is conducted in the rural area ${ }^{22}$ or close to the rural area (like in this study), there is a high prevalence of neurotic disorders. This is just the possible hypothesis which needs to confirm/reject with large scale comparative studies. This could be due to the fact that long standing somatic symptoms of neurotic disorders make the patient to visit multiple hospitals to relieve their distress immediately. ${ }^{24}$

The prevalence of organic, including symptomatic, mental disorders was $7.7 \%$ in the present study. The different studies found prevalence of $11.9 \%,{ }^{18} 12 \%,{ }^{16}$ $15 \%,{ }^{17,23}$ and $15.9 \% .^{13}$

The diagnosis of mental and behavioral disorders due to psychoactive substance use constitutes $3.8 \%$ of the total sample in the current sample. This patient was diagnosed to be suffering from alcohol dependence syndrome. Other studies done previously in Nepal found prevalence of $5 \%,{ }^{25} 10.5 \%,{ }^{14} 12.9 \%,{ }^{15} 14 \%,{ }^{23} 18.1 \%{ }^{13}$ and $19 \% .^{16}$

The prevalence of schizophrenia, schizotypal, and delusional disorders was $3.1 \%$ in the current sample. The prevalence of schizophrenia ranges from $6 \%$ to $33.3 \%$ according to different studies have done both inside Nepal and India. ${ }^{13-16,18,23}$

The prevalence of mood disorder (which includes both depressive episodes and bipolar disorders) in the current study was $28.3 \%$. The prevalence found in other studies were $19.5 \%,{ }^{14} 32.5 \%,{ }^{23} 39.1,{ }^{13} 44.0 \%,{ }^{18}$ $44.8 \%{ }^{15}$ and $46 \% .{ }^{16}$ The study conducted in tertiary care hospital in Nepal found a prevalence of depression of $53.2 \%$ according to the Geriatric Depression Scale. ${ }^{26}$

The proportion of elderly patients to be suffering from neurotic, stress-related, and somatoform disorders was $37.0 \%$ in this study. The other study done in Nepal found a prevalence of $23.3 \%$ and $2.5 \%$ of anxiety disorder and somatoform disorder respectively. ${ }^{23}$ Two studies done in the Eastern region of Nepal found a prevalence of $22 \%{ }^{16}$ and $13.8 \% .^{15}$

In the gender distribution of the current study samples, the psychiatric diagnosis was more prevalent in females as compared to males except in mental and behavioral disorders due to psychoactive substance use. One study conducted in the same Province area as the current study also found more elderly males to be suffering from alcohol dependence syndrome. ${ }^{25}$ One study done in Nepal found more prevalence of alcohol dependence and dementia in the male population. ${ }^{13}$ There is more prevalence of all psychiatric diagnoses in the patients less than or equal to 75 in this study. One study found that except for dementia, there is more prevalence of psychiatric diagnosis at the age of less than or equal to 
Khattri et al. Psychiatric Morbidities of Elderly Out-patients Attending Various Out-reach Clinics in Gandaki Province of Nepal...

75 years as compared to above 75 years. ${ }^{23}$ This overall finding might just be due to the small sample size of patients above 75 years in the current study.

The reasons for the study findings of the different studies might be due to the difference in the sample characteristics of the study populations. The different study design and confounding factors in various studies may lead to different findings. The use of different assessment tools and study settings (out-patient, inpatient, and rural setting) might be the other reason for the difference in the study findings.

There are limitations to this study. The use of ICD for diagnosis of psychiatric disorder in an elderly sample may underestimate its true prevalence. Also, as this study was conducted in the outpatient department settings, the finding cannot be generalized to the entire population.

\section{CONCLUSIONS}

The study found that the majority of the elderly patients who visited the out-reach clinics were from the age groups between 66 and 75 years, Brahmin and Chhetri caste, females, married, and living in the extended nuclear family. The maximum patients were also found to be suffering from the neurotic, stressrelated, and somatoform disorder which is followed by a mood disorder. This study finding would be helpful in the identification and holistic management of elderly patients. Further large scale, case-control, and analytical design studies in the community setting in a different region of Nepal are required before generalizing the result of this study.

Conflict of Interest: None.

\section{REFERENCES}

1. Kinsella K, Velkoff VA. The demographics of aging. Aging Clinical and Experimental Research. 2002;14:159-69. [ull Text]

2. Harper S. Economic and social implications of aging societies. Science. 2014 Oct 31;346(6209):587-91. [․ㅏbMed | Full Text | DOI]

3. United Nation Publication Fund; Help Age International. Ageing in the twenty-first century: a celebration and a challenge [Internet]. New York: United Nation Publication Fund; 2012 [cited 2020 May 12]. 192p. Available from: https://www.unfpa.org/sites/default/files/pub-pdf/ Ageing\%20report.pdf. [Full Text]

4. Central Bureau of Statistics. National Population and Housing Census 2011. Kathmandu: Central Bureau of Statistics; 2012 Nov. 270p. [Full Text]

5. Gelder MG, Andreasen NC, Lopez-Ibor Jr JJ, Geddes JR. New Oxford textbook of psychiatry. 2nd ed. Oxford: Oxford University Press; 2009. [Full Text]

6. Jeste DV, Alexopoulos GS, Bartels SJ, Cummings JL, Gallo JJ, Gottlieb GL, et al. Consensus statement on the upcoming crisis in geriatric mental health: research agenda for the next 2 decades. Arch Gen Psychiatry. 1999 Sep;56(9):848-53. [uued | Full Text | DOI]

7. Khattri JB, Poudel BM, Thapa P, Godar ST, Tirkey S, Ramesh K, et al. An epidemiological study of psychiatric cases in a rural community of Nepal. Nepal Journal of Medical Sciences. 2013;2(1):52-6. [Full Text | DOI]

8. World Health Organization. The ICD-10 classification of mental and behavioral disorders diagnostic criteria for research. Geneva: World Health Organization; 1992. [Full Text]
9. Silva Pereira YD, Estibeiro A, Dhume R, Fernandes J. Geriatric patients attending tertiary care psychiatric hospital. Indian J Psychiatry. 2002 Oct;44(4):326-31. [PubMed | Full Text]

10. Rao VA, Viruthagirinathan BS, Malathi R. Mental illness in patients aged fifty and over. Indian J Psychiatry. 1972;14(3):319-32. [Full Text]

11. Bhogale GS \& Sudarshan CY. Geriatric patients attending general hospital psychiatric clinic. Indian J Psychiatry. 1993 Oct-Dec;35(4):203-5. [Full Text]

12. Prasad KMR, Sreenivas KN, Ashok MV, Bagchi D. Psychogeriatrics patients - a sociodemographic and clinical profile. Indian J Psychiatry. 1996 Jul-Sep;38(3):178-81. [Full Text]

13. Aich TK, Dhungana M, Muthuswamy R. Pattern of neuropsychiatric illness in older age group population: an inpatient study report from Nepal. Indian J Psychiatry. 2012 Jan;54(1):23-31. [uued | Full Text | DOI]

14. Aich TK, Shah S, Subedi S. Pattern of neuropsychiatric illnesses in geriatric population: an outpatient study report. Journal of Psychiatrists' Association of Nepal. 2015;4(1);12-9. [Full Text | DOI]

15. Nepal S, Sapkota N, Kumar R, Deo BK, Mishra S. Psychiatric disorders in elderly patients attending OPD of tertiary care centre in eastern region of Nepal. Journal of Psychiatrists' Association of Nepal. 2016;5(1):43-8. [Full Text | DOI]

16. Shakya DR. Psychiatric morbidities of elderly psychiatric outpatients in a tertiary care hospital. Journal of College of Medical Sciences-Nepal. 2011;7(4):1-8. [ Full Text | DOI] 
17. Khattri JB, Nepal MK. Sociodemographic characteristic and organic mental disorders among elderly citizens attending tertiary care teaching hospital in Nepal. Stupa Journal of Health Sciences. 2007;3:67-72.

18. Tiple P, Sharma SN, Srivastava AS. Psychiatric morbidity in geriatric people. Indian J Psychiatry. 2006 Apr;48(2):88-94. [PubMed | Full Text | DOI]

19. Manandhar K, Risal A, Shrestha O, Manadhar N, Kunwar D, Koju R, et al. Prevalence of geriatric depression in the Kavre district, Nepal: findings from a cross sectional community survey. BMC Psychiatry. 2019;19(1):271. [PubMed | Full Text | DOI]

20. Koirala NR, Mahat P, Nepal MK, Ojha SP, Sinha UK, Pokhrel A, et al. Geriatric psychiatry: socio-demographic characteristics and diagnostic profile among senior citizens attending the psychiatric outpatient department of a tertiary health care facility in Nepal. Journal of Institute of Medicine. 2000;22:221-6.

21. Nandi PS, Banerjee G, Mukherjee SP, Nandi S, Nandi DN. A study of psychiatric morbidity of the elderly population of a rural community in West Bengal. Indian J Psychiatry. 1997 Apr;39(2):122-9. [PubMed | Full Text]
22. Subedi S, Tausig M, Subedi J. Mental illness and disability among elders in developing countries: the case of Nepal. J Aging Health. 2004 Feb;16(1):71-87. [PubMed | Full Text | DOI]

23. Thapa P, Chakraborty PK, Khattri JB, Ramesh K, Sharma B. Psychiatric morbidity in elderly patients attending OPD of tertiary care centre in western region of Nepal. Ind Psychiatry J. 2014 Jul-Dec;23(2):101-4. [PubMed | Full Text $\mid \underline{\mathrm{DOI}}]$

24. Khattri JB, Godar ST, Thapa P, Ramesh K, Chakrabortty PK, Thapa BB. Socio-demographic characteristics and diagnostic profile of patients attending Psychiatric OPD of a private hospital in western region of Nepal. Nepal Journal of Medical Sciences. 2012;1(1):15-8. [Full Text | $\underline{\mathrm{DOI}}]$

25. Khattri JB, Poudel BM, Godar ST, Ramesh K, Chakrabortty PK, Thapa BB. Alcohol dependence syndrome among older adults attending psychiatry OPD of a private hospital in western region of Nepal. Nepal Journal of Medical Sciences. 2012;1(1):39-41. [․ㅏll Text | DOI]

26. Khattri JB, Nepal MK. Study of depression among geriatric population of Nepal. Nepal Med Coll J. 2006 Dec;8(4):220-3. [ 